UDC 101.1:316

DOI https://doi.org/10.30970/2307-1664.2019.24.14

\title{
SOCIO-PHILOSOPHICAL ANALYSIS OF THE CATEGORY “FREEDOM"
}

\author{
Ilham Soltanov \\ National Academy of Sciences of Azerbaijan, Institute of Philosophy, \\ Department of Social Philosophy and Ecology \\ G. Javid Ave, 115, Baku, Azerbaijan Republic, AZ1073
}

The article analyzes the problem of individual freedom, expresses attitudes towards different views and opinions. It is noted that the concept of individual freedom is characterized by an extremely complex, multidimensional, multidisciplinary and multi-faceted character, depending on its nature. Attention is drawn to the fact that for a comprehensive and in-depth study of the essence of the problem of individual freedom, contemporary content, relations with other values in society, innovations occurring in conjunction with morality and law, first of all, methodological issues associated with it are required. Otherwise, it is impossible to give a general philosophical adequate concept of individual freedom and, in particular, to determine its place and role in the system of social and philosophical categories.

The article examines issues in the context of radical changes in society and the expansion of globalization trends on a global scale, the rethinking of the value system, the development of people's worldview and self-awareness, which stimulate an individual to freedom and problems that contradict it.

It should be noted that regardless of the form in which freedom is expressed, this aspect should always be in the center of attention: freedom is an attributive quality arising from the inner essence of a person, that is, it is not a temporary or random sign given by someone. It is based on the conscious choice of a person who is an active and creative entity. This choice does not take place voluntarily, is carried out within the framework of the existing necessity and its possibilities, cannot go beyond them.

Thus, objective necessity was not abstract; it finds its concrete embodiment in separate actions of the subject. As a result, necessity does not act as an external force in relation to man, but is realized in the framework of practical activities. An important feature of the objective laws of social development is that they allow people to make choices not only within the framework of necessity, but also allow them to exert a conscious influence on the process of its implementation and change. In addition to the above, it is necessary to show that social need has a very complex content.

Key words: personal freedom, concept, value, law, analysis.

For a comprehensive and in-depth study of the essence of the problem of individual freedom, contemporary content, relationships with other values in society, innovations that take place in conjunction with morality and law, first of all, it is necessary to consider the methodological issues associated with it. Otherwise, it is impossible to give a general philosophical adequate concept of individual freedom and, in particular, to determine its place and role in the system of social and philosophical categories.

The need to study the socio-philosophical essence of individual freedom is due to the following two reasons. First, despite the sufficiency of freedom and the fact that their overwhelming majority was written in Soviet times, they focused on the general and more political and practical roles of this concept, their place in the system of socio-philosophical classification was not adequately covered. Secondly, the significant changes occurring in our country, the expansion of globalization trends throughout the world, the rethinking of the value system, the development of people's outlook and self-esteem, and others. The process creates many qualitative improvements in the internal content of this concept, as well as with other concepts of social philosophy, whose analysis and synthesis is important from a scientific and practical point of view.

(C) I. Soltanov, 2019 
Personal freedom is directly related to the daily life and activities of people. It is also inseparable from the interests of each person and, in general, of society. Therefore, all members of society are deeply interested in freedom. But in order to clearly and comprehensively present the realistic side of ideas and the universal value of freedom, it is first of all necessary to have its scientific and theoretical meaning. In the history of philosophy and public opinion there is practically no thinker who would not express his opinion about the idea of freedom. Along with this, it should be noted that due to the fact that it has an extensive content and complex essence, it is changeable and flexible in the historical process, is interpreted differently (even sometimes opposite to each other). Emphasizing this quality of freedom, Hegel wrote: "They rightfully do not speak of any idea as freedom, that this idea is vague, polysemantic, can give rise to the greatest misunderstandings and therefore, it really gives rise" (7, p. 253).

In general, in philosophy, the tradition of approaching freedom as a necessity is widespread. His roots go back to the scientific work of B. Spinoza (8, p. 194). Later this idea was again emphasized in the work of F. Engels "Anti-Dühring". He described the essence of freedom as follows: "Freedom is not in an imaginary dependence on the laws of nature, but in the ability to direct the laws of nature to specific goals, aware of all laws and based on this knowledge. This applies to both external natural laws and the laws governing the physical and spiritual essence of man" (4, p. 116).

It is worth noting that in modern socio-philosophical literature there is almost no general definition of freedom. Most authors are limited to showing it as a necessity. In our opinion, such an approach, of course, causes a certain scientific interest, but this cannot be limited to. First of all, the question of what a necessity is and how it is perceived remains open (we note that it is not in itself an unambiguous process and goes through various internal stages). On the other hand, the connection between freedom and necessity comes to the fore, the inner content, the important and distinguishing features of this understanding are not disclosed to the necessary extent.

In general, in philosophical literature there are two views in explaining the concept of freedom (too limited and too extended). The first expression found in the "Philosophical Encyclopedia": "Freedom is a conscious need and behavior of a person in accordance with his knowledge, ability and choice in his actions" (5, p. 559).

As you know, here the concept of freedom is characterized only as a conscious need and the ability of a person to choose on the basis of the knowledge he possesses. In other words, the objective and subjective factors causing freedom, as well as its socio-psychological characteristics, were not revealed.

Another excessive limit is the position of expanded reflection on freedom, which is reflected in the definition given by L. Stolovich: "Any type of activity - changing the world, understanding it, accepting values, and even communicating between people - can be viewed as freedom. Free action involves understanding the necessity, creating something skillfully and subtly, the properties of labor materials and tools, as well as a clear definition of the direction of activity" (9, p. 67).

Upon careful consideration of this definition, it turns out that it covers everything. Nothing in public life exists outside of it. In our opinion, such an approach to freedom does not justify itself, because, although it is in an indefinite form, the impression is created that there is no other concept in social science than "freedom" and there is no need for it in it.

Although it is difficult to define freedom, it is imperative to try to determine its burden. In our opinion, from the point of view of the disclosure of the socio-philosophical content of freedom, the following definition, which we offer, may be acceptable: "Freedom is the ability to actively and freely realize the potential life force, its own needs, interests and desires, based on knowledge and social experience within the existing conditions and opportunities created by the existing society" (2).

This definition is of great scientific interest, since it lists all the key elements that determine the content of freedom. In addition, the logical focus is on two main aspects. First, a person can make 
free choice and act freely only when real conditions can be achieved, when the subject can have comprehensive knowledge of existing alternatives. Another important point is that people have a clear and clear view of their own needs, interests and goals. By the way, sometimes in the philosophical literature there are cases when the role of the latter is assessed insufficiently, which is wrong (2, p. 166).

It should be noted that regardless of the form in which freedom is expressed, this aspect should always be in the center of attention: freedom is an attributive quality arising from the inner essence of a person, that is, it is not a temporary or random sign given by someone. It is based on the conscious choice of a person who is an active and creative entity. This choice does not take place voluntarily, is carried out within the framework of the existing necessity and its possibilities, cannot go beyond them. On the other hand, the nature of the relationship between objective necessity and human freedom is not decisive and unequivocal in nature (1, p. 143). In other words, due to the fact that man is a conscious being, he in a particular condition makes a free choice between all sorts of options dictating an objective condition, stands on one of them and makes a decision about its implementation. After that, his freedom is expressed in determining the goal of this decision, in finding the path and means of achieving it, in choosing, in realizing it.

From those noted, it becomes clear that even the most general sense of freedom does not present it as an instantaneous act, but is accepted as a long process through a series of successive phases interacting with each other. The main stages of this process are the following: based on knowledge of nature and public life, the choice by the subject of his will one of the alternatives to real life, the nomination of the goal in the direction of its implementation, the definition of effective ways and means for this, and their implementation.

In general, social freedom has certain peculiarities in relation to each subject of a social entity that exists in society (a separate individual, collective, social unity, ethnic unity, etc.).

The relationship between these species appears as a relationship of the general, the particular and the single. In this regard, it should, however, be noted that sometimes such a false concept is put forward that the role and significance of personal and group forms of freedom are limited as communication increases and shades increase in different aspects of social life, because an increase in social content in freedom is characterized automatically reducing the weight of individual and personal parties $(3, \mathrm{p} .153)$. In fact, these views are scientifically unjustified because, in society, social, group and personal interests are inseparable from each other. Therefore, social and personal forms of freedom cannot be presented separately from each other, they are linked by strong ties. Personal freedom can express its true essence only in interaction with the individual and other people in the system of social relations.

It should be noted that since the concept of freedom of expression is inherently complex, multidimensional, multidirectional and multi-level, its research should be based on the methodology of systematic analysis. Each step in this direction should, first of all, be based on a theoretical position, according to which society and people are objective and interconnected on a multilateral basis. The system analysis method, which occupies an exceptional place in the explanation of social events, shows the mutual influence and interdependence of these two sides. Universal interaction and attitude show that there are very different options, opportunities and trends, they exclude the final and one-sided dependence, show that the latter acts as a spectrum of many possibilities. This situation constantly challenges the person to make a free choice and make a decision $(6, p .12)$. Thus, objective necessity was not abstract; it finds its concrete embodiment in separate actions of the subject. As a result, necessity does not act as an external force in relation to man, but is realized in the framework of practical activities. An important feature of the objective laws of social development is that they allow people to make choices not only within the framework of necessity, but also allow them to exert a conscious influence on the process of its implementation and change. In addition to the above, it is necessary to show that social need has a very complex content. 


\title{
References
}

1. Cəfərova V. Azərbaycan müstəqillik yollarında: problemlər, mülahizələr. Bakı : Çasığlu, 2013. 119 c.

2. Давидович В.Е. Грани свободы. Москва : Молодая гвардия, 1969. 224 с.

3. Oliyev Q. Çağdaş demokratik proseslərin bəzi fəlsəfi problemləri. Bak1 : Təbib, 1997. $129 \mathrm{~s}$.

4. Энгельс Ф. Анти-Дюринг. Москва : Политиздат, 1988. I-XII, 482 с.

5. Fəlsəfə ensiklopedik lüğəti. Müəlliflər kollektivi. Azərbaycan Ensiklopediyas1, 1997. 3 saylı Bakı Mətbəəsi ASC, 308 s.

6. Hacıyev Z. Keçid dövrü və sosial dəyərlər. BDU-nun xəbərlari. Sosial siyasi elmlər. 2012. № 3-4.

7. Гегель. Сочинения: В 14-ти т. Т. 3. Москва : Мысль, 1966. 472 с

8. Спиноза Б. Избранные произведения: В 2-х т. Т. 1. Москва: Изд-во: Мысль, 1957. 590 с.

9. Столович Л.Н. Жизнь - творчество - человек. Москва : Мысль, 2011. 364 с.

\section{СОЦІАЛЬНО-ФІЛОСОФСЬКИЙ АНАЛІЗ КАТЕГОРІЇ «СВОБОДА»}

\author{
Ільхам Солтанов \\ Наиіональна академія наук Азербайджсну, Інститут філософії, \\ відділ соиіальної філософії і проблеми екології \\ пр. Г. Джавіда, 115, м Баку, Азербайджанська Республіка, AZ1073
}

У статті аналізується проблема свободи особистості, висловлюється ставлення щодо різних поглядів і думок. Зазначається, що концепція свободи особистості характеризується надзвичайно складним, багатовимірним, багатопрофільним і багатоплановим характером залежно від його природи. Звертається увага на те, що для всебічного і глибокого вивчення суті проблеми свободи особистості, сучасного змісту, відносини з іншими цінностями в суспільстві, нововведень, що відбуваються у взаємозв'язку з мораллю і правом, перш за все, потрібно розглянути методологічні питання, пов'язані з ним. В іншому разі неможливо дати філософський адекватне поняття свободи особистості i, зокрема, визначити його місце і роль у системі соціально-філософських категорій.

Досліджуються питання в контексті радикальних змін у суспільстві і розширення тенденцій глобалізації в світовому масштабі, переосмислення системи цінностей, розвитку світогляду і самосвідомості людей, що сприяють стимуляції особистості до свободи.

Варто зазначити, що незалежно від того, в якій формі виражається свобода, такий аспект завжди має бути в центрі уваги: свобода - це атрибутивна якість, що випливає з внутрішньої сутності людини, тобто це не тимчасовий або випадковий ознака, даний кимось. Ї̈ї основу становить усвідомлений вибір людини, що є активною і творчою сутністю. Цей вибір відбувається не зі своєї волі, здійснюється в рамках наявної необхідності і її можливостей, не може вийти за їх межі.

Таким чином, об'єктивна необхідність не була абстрактною, знаходить своє конкретне втілення в окремих діях суб'єкта. В результаті необхідність не діє як зовнішня сила щодо людини, а реалізується в рамках практичної діяльності. Важлива особливість об'єктивних законів суспільного розвитку полягає в тому, що вони дають змогу людям робити вибір не тільки в рамках необхідності, але також дозволяють надавати свідомий вплив на процес його реалізації і зміни. Крім того, треба показати, що соціальна необхідність має дуже складний зміст.

Ключові слова: свобода особистості, концепція, цінність, закон, аналіз. 